\title{
Bibliography of Professor Krzysztof Sobczyk
}

\section{MONOGRAPHS}

1. 1987 The Upper Palaeolithic site Kraków Spadzista street C2 (excavations 1980), (in:) B. Ginter (ed.), Prace Archeologiczne, 42, Warszawa-Kraków (co-author: J. K. Kozłowski, with contributions: S. Alexandrowicz, K. Konecka-Betley, H. Kubiak, M. Pawlikowski).

2. 1993 The Late Palaeolithic flint workshops at Brzoskwinia-Krzemionki near Kraków, (in:) Prace Archeologiczne, 55, Kraków.

3. 1995 Osadnictwo wschodniograweckie $w$ dolinie Wisty pod Krakowem, Prace habilitacyjne UJ, 303, Kraków.

4. 1995 Complex of Upper Palaeolithic Sites near Moravany. Western Slovakia: Vol. I Moravany-Žakovska (excavations 1991-1992), Kraków (co-authors: J. Hromada, J. K. Kozłowski, with co-collaboration: S.W. Alexandrowicz, L. Bánesz, B. Kazior, H. Kubiak, M. Lityńska-Zając, M. Pawlikowski. A. Pazdur, J. Trąbska).

5. 1999 Les chasseurs de mammouths de la vallée de la Vistule: Krakow-Spadzista B, un site gravettien à amas d'ossements de mammouths, Monographies de Préhistoire Générale, 4, Bruxelles (co-authors: C. Escutenaire, J. K. Kozłowski, V. Sitlivy).

6. 2008 (editor) Middle and Early Upper Palaeolithic of the Krakow Region: Piekary IIa, Monographies de Préhistoire Générale, 6, Bruxelles (co-editors: V. Sitlivy, A. Zięba).

7. 2009 (editor) Middle and Early Upper Palaeolithic of the Krakow Region: Księcia Józefa, Monographies de Préhistoire Générale, 7, Bruxelles (co-editors: V. Sitlivy, A. Zięba).

8. 2014 The middle-to-upper palaeolithic Księcia Józefa open-air site (Krakow, Poland): lithic technology and spatial distribution, Universitätsforschungen zur prähistorischen Archäologie, 250, Bonn (co-authors: V. Sitlivy, A. Zięba, A. Kolesnik).

9. 2018 (editor) Multas Per Gentes Et Multa Per Saecula. Amici Magistro Et Collegae Suo Ioanni Christopho Kozłowski Dedicant, Kraków (co-editors P. Valde-Nowak, M. Nowak, J. Źrałka).

\section{RESEARCH PAPERS}

10. 1973 Zastosowanie taksonomii numerycznej do analizy typologicznej na przykładzie noży prądnickich, Sprawozdania z posiedzeń Komisji Nauk. Oddział PAN w Krakowie, 17 (2), pp. 255-269.

11. 1975 Problem prądnika $w$ świetle taksonomii numerycznej, Sprawozdania Archeologiczne, 27, pp. 255-269. 
12. 1976 Dolnopaleolityczne stanowisko w Raciborzu-Studziennej, woj. Katowice, Sprawozdania Archeologiczne, 28, pp. 11-18.

13. 1976 Field survey in the western part of the district of Cracow, autumn 1974, Recherches Archeologiques de 1974, pp. $72-76$ (co-authors: B. Drobniewicz, Z. Pianowski).

14. 1976 Brzoskwinia-Krzemionki: Province of Kraków (The Group of Palaeolithic Sites), Recherches Archeologiques de 1975, pp. 5-10 (co-authors: A. Dagnan-Ginter, B. Drobniewicz, B. Ginter).

15. 1977 Brzoskwinia-Krzemionki: Zabierzów Community, Province of Cracow (The Group of Palaeolithic Sites), Recherches Archeologiques de 1976, pp. 5-7 (co-authors: B. Drobniewicz, B. Ginter, J. K. Kozłowski).

16. 1978 Brzoskwinia-Krzemionki, province of Cracov (A complex of Terminal Palaeolithic workshop site), Recherches Archeologiques de 1978, pp. 5-7 (co-authors: B. Drobniewicz, B. Ginter).

17. 1982 Spadzista street, site C2 (Upper Palaeolithic site), Recherches Archeologiques de 1980, pp. 5-8 (co-authors: B. Drobniewicz, E. Chochorowska, J. K. Kozłowski).

18. 1984 Modes de débitage dans le Magdalénien d'Europe central, L'Anthropologie, 88, pp. 309-326.

19. 1985 Kraków-Przegorzały (Eine oberpaläolitische Lößfundstelle), Recherches Archeologiques de 1983, pp. 5-6 (co-author: J. K. Kozłowski).

20. 1985 Modes de debitage dans le Magdalénien d'Europe Central, Recherches Archeologiques de 1983, pp. 80-94.

21. 1986 Biały Kościót, Province of Kraków, community Wielka Wieś, Big Cave at Mączna Skata, Recherches Archeologiques de 1984, pp. 5-6 (co-authors: A. Dagnan-Ginter, B. Drobniewicz).

22. 1987 Kraków, Spadzista Street B “workshops” (The Upper Palaeolithic workshop site), Recherches Archeologiques de 1985, pp. 5-7.

23. 1988 Kraków, Spadzista Street, site “D” (An Upper Palaeolithic site), Recherches Archeologiques de 1986, pp. 5-6.

24. 1989 Kraków, rue Spadzista “D” et “E” (Les sites du Paléolithique supérieur), Recherches Archaeologiques de 1987, pp. 5-6.

25. 1990 Sromowce Wyżne, Province of Nowy Sacz, site 8 (workshop site, late Palaeolithic?), Recherches Archeologiques de 1988, pp. 5-6 (co-author: B. Drobniewicz).

26. 1990 Kraków, Spadzista Street B1 and F (Complex of Upper Palaeolithic sites and camps), Recherches Archeologiques de 1989, pp. 5-10.

27. 1992 Wołowice, Province of Kraków, Flint extraction and processing site, Recherches Archeologiques de 1990, pp. 5-25 (co-authors: Cz. Bańdo, A. Dagnan-Ginter, S. Holen, J. K. Kozłowski, A. Montet-White, M. Pawlikowski).

28. 1992 Le site de plesi air du Paléolithiquie supérieur de Kašov 1 en Slovaquie orientale (Etude préliminaire d'une structure spatiale des outillages épigravettiens en obsidienne), Slovenská Archeológia, 40 (1), pp. 5-28 (co-authors: L. Bánesz, J. Hromada, R. Desbrosse, I. Margerand, J. K. Kozłowski, M. Pawlikowski).

29. 1993 Výskum epigravettienskej stanice v Moravanoch nad Váhom-Žákovskej, Archeologické Výskumy a Nálezy na Slovensku v 1992, pp. 52-55 (co-authors: J. Hromada, L. Bánesz, J. K. Kozlowski).

30. 1993 Les Couteaux micoquiens du Würm ancient, Prehistoire Europeenne, 4, pp. 9-32 (coauthors: L. Kulakovskaya, J. K. Kozlowski).

31. 1994 Classification des "Prondniks" à partir de l'analyse des correspondances, L'Anthropologie, 98 (2-3), pp. 364-378. 
32. 1994 Mikokskiye nozhi: Opriedeleniye i klasifikaciya, Archeologicheskii Almanach, 3, pp. 56-71 (co-authors: L.V. Kulakovskaya, Ya.K. Kozlovskiy).

33. 1995 Výskum mladopaleolitickej stanice v Moravanoch nad Váhom-Lopate II, Archeologické Výskumy a Nálezy na Slovensku v 1993, pp. 58-60 (co-authors: J. Hromada, L. Bánesz, B. Kazior, J. K. Kozlowski).

34. 1995 Site formation processes in loess areas: A case study from Moravany-Žakovska, Western Slovakia, Geoarchaeology: An International Journal, 10 (4), pp. 237-255 (coauthors: L. Bánesz, J. Hromada, J. K. Kozlowski, M. Pawlikowski).

35. 1996 Prehistoric settlement in the Klisoura Gorge, Argolid, Greece (excavations 1993, 1994), Préhistoire Européenne, 8, pp. 143-173 (co-authors: M. Koumouzelis, J. K. Kozłowski, M. Nowak, M. Kaczanowska, M. Pawlikowski, A. Pazdur).

36. 1996 Pokračovanie výskumu gravettienskej stanice v Moravanoch nad Váhom - Lopate II, Archeologické Výskumy a Nálezy na Slovensku v 1994, pp. 92-94 (co-authors: J. Hromada, L. Bánesz, B. Kazior, J. K. Kozlowski).

37. 1996 Prieskum doliny strednej Tople, Archeologické Výskumy a Nálezy na Slovensku v 1994, pp. 179-180 (co-authors: M. Vizdal, J. Harčár, M. Kaczanowska, L. Kaminská, J. K. Kozłowski, M. Nowak, M. Pawlikowski).

38. 1997 Tretia sezóna výskumu mladopaleolitickej stanice v Moravanoch nad Váhom Lopate II, Archeologické Výskumy a Nálezy na Slovensku v 1995, pp. 82-84 (co-authors: J. Hromada, L. Bánesz, B. Kazior, J.K. Kozlowski).

39. 1997 Korelácia sprašových profilov na základe mineralogických, malakologických a antropogenetických údajov podl'a výsledkov archeologických výskumov v Moravanoch (Lopata II) v okoli minerálnych prameňov pri Piešt’anoch, Balneologický Spravodajca, 35, pp. 175-194 (co-authors: M. Pawlikowski, W. P. Alexandrowicz, J. K. Kozłowski, B. Kazior, L. Bánesz, J. Hromada).

40. 1998 Correlation between Loess Profiles on the Basic of Mineralogical, Malacological and Anthropogenic Indicators: A Case Study from Moravany-Lopata, Western Slovakia, Geoarchaeology: An International Journal, 13 (6), pp. 565-594 (co-authors: M. Pawlikowski, W. P. Alexandrowicz, L. Bánesz, J. Hromada, J. K. Kozłowski, B. Kazior).

41. 1999 Piekary IIa Palaeolithic industries: Preliminary results of a New Multidisciplinary Investigations, Préhistoire Européenne, 15, pp. 45-64 (co-authors: V. Sitlivy, W. Morawski, A. Zięba, C. Escutenaire).

42. 1999 The new Palaeolithic sites of Księcia Józefa (Cracow, Poland) with blade and flake reductions, Préhistoire Européenne, 15, pp. 87-111 (co-authors: V. Sitlivy, T. Kalicki, C. Escutenaire, A. Zięba, K. Kaczor).

43. 2001 La fin du Paléolithique moyen et le début du Paléolithique supérieur en Grèce: La séquence de la Grotte 1 de Klissoura, L'Anthropologie, 105 (4), pp. 469-504 (co-authors: M. Koumouzelis, J. K. Kozlowski, C. Escutenaire, V. Sitlivy, H. Valladas, N. TisneratLaborde, P. Wojtal, B. Ginter, M. Kaczanowska, B. Kazior, A. Zieba).

44. 2003 Luminescens dates for the palaeolithic site of Piekary IIa (Poland): comparison between TL of burnt flints and OSL of a loess-like deposit, Quaternary Science Reviews, 22, pp. 1245-1249 (co-authors: N. Mercier, H. Valladas, L. Froget, J-L. Joron, J-L. Reyss, S. Balescu, C. Escutenaire, J. Kozłowski, V. Sitlivy, A. Zięba).

45. 2003 Dating the Late Middle Palaeolithic technologies and transition to the Upper Palaeolithic in southern Poland, Eurasian Prehistory, 1 (1), pp. 57-82 (co-authors: H. Valladas, N. Mercier, C. Escutenaire, T. Kalicki, J. Kozłowski, V. Sitlivy, A. Zięba). 
46. 2004 Résultats préliminaires de la fouille des sites de Spadzista (campagne de 1997), Recherches Archeologiques de 1993-1998, pp. 17-25 (co-authors: C. Escutenaire, V. Sitlivy).

47. 2004 Cave 1 in Klisoura Gorge (Greece), Recherches Archeologiques de 1993-1998, pp. 206-220 (co-authors: M. Koumouzelis, B. Ginter, J. K. Kozłowski, B. Kazior).

48. 2004 The eastern Gravetian settlement in the Vistula valley near Kraków, Recherches Archeologiques de 1993-1998, pp. 281.

49. 2004 The earliest evidence for clay hearths: Aurignacian features in Klisoura Cave 1, southern Greece, Antiquity, 78 (301), pp. 513-525 (co-authors: P. Karkanas, M. Koumouzelis, J. K. Kozlowski, V. Sitlivy, F. Berna, S. Weiner).

50. 2005 Man and wooly mammoth at the Kraków Spadzista Street (B) - tafonomy of the site, Journal of Archaeological Science, 32, pp. 193-206 (co-author: P. Wojtal).

51. 2006 Les fouilles préhisoriques dans les grottes d'Ojców (1998-2003), Recherches Archeologiques de 1999-2003, pp. 9-13 (co-authors: C. Escutenaire, A. Kolesnik, B. Miękina, J. Richter, V. Sitlivy, A. Zięba, A. Veselski, G. Lipecki, P. Wojtal).

52. 2006 Les sites de plain air du Paléolithique supérieur et moyen de la région de Cracovie. Spadzista B1, Piekary IIa, Kraków - ul. Księcia Józefa (2000-2002), Recherches Archeologiques de 1999-2003, pp. 14-24 (co-authors: C. Escutenaire, V. Sitlivy, A. Zięba).

53. 2006 Rapport préliminaire des fouilles en Grèce - 2001-2003. Grotte de Klisoura, Recherches Archeologiques de 1999-2003, pp. 293-298 (co-authors: M. Koumouzelis, J. K. Kozłowski, B. Ginter, M. Kaczanowska, C. Escutenaire, V. Sitlivy).

54. 2007 Middle Paleolithic lithic assemblages of the Klissoura cave, Peloponnesus, Greece: A comparative analysis, Archaeology, Ethnology and Anthropology of Eurasia, 31 (1), pp. 2-15 (co-authors: V. Sitlivy, P. Karkanas, M. Koumouzelis).

55. 2008 Stratigraphic Sequence of Late Quaternary Deposits and Palaeolithic Occupations in the Trenčianska Turná Microregion, Slovenská Archeológia, 56 (2), pp. 239-253 (coauthors: A. Budek, T. Kalicki, L. Kaminská, J. K. Kozłowski).

56. 2008 Raw Material Exploitation and Intra-site Spatial Distribution at Two Late Middle and Early Upper Palaeolithic Sites in the Cracow Region: Piekary IIa and Ksiecia Jozefa, Archaeology, Ethnology and Anthropology of Eurasia, 33 (1), pp. 46-57 (V. Sitlivy, P. Karkanas, M. Koumouzelis).

57. 2009 The New Middle Palaeolithic Human Occupations in Cave 1 in Klissoura, Greece. The Investigations in 2004-2006, Recherches Archeologiques Nouvelle Serie, 1, pp. 377395 (co-authors: V. Sitlivy, M. Koumouzelis, P. Karkanas).

58. 2012 Spatial organization of the Gravettian mammoth hunters' site at Kraków Spadzista (southern Poland), Journal of Archaeological Science, 39 (12), pp. 3627-3642 (co-authors: J. Wilczyński, P. Wojtal).

59. 2014 Middle Paleolithic sequences of the Ciemna Cave (Pradnik valley, Poland): The problem of synchronization, Quaternary International, 326-327, pp. 125-145 (co-authors: P. Valde-Nowak, B. Alex, B. Ginter, M. T. Krajcarz, T. Madeyska, B. Miękina, D. Stefański, P. Wojtal, M. Zając, K. Zarzecka-Szubińska).

60. 2014 Badania w Jaskini Ciemnej w roku 2014, Prądnik. Prace i Materiały Muzeum im. prof. Władysława Szafera, 24, pp. 151-156 (co-authors: B. Ginter, D. Stefański, P. ValdeNowak, M. Zając).

61. 2015 Kraków Spadzista trench C2 - new research and interpretations of Gravettian settlement, Quaternary International, 359-360, pp. 96-113 (co-authors: J. Wilczyński, P. Wojtal, D. Sobieraj). 
62. 2015 The loess-palaeosol sequence in the Upper Palaeolithic site at Kraków Spadzista: A palaeoenvironmental approach, Quaternary International, 365, pp. 98-113 (co-authors: M. Łanczont, T. Madeyska, P. Mroczek, M. Komar, B. Łącka, A. Bogucki, J. Wilczyński).

63. 2016 Mammoth hunting - Impact traces on backed implements from a mammoth bone accumulation at Kraków Spadzista (southern Poland), Journal of Archaeological Science, 65, pp. 122-133 (co-authors: B. Kufel-Diakowska, J. Wilczyński, P. Wojtal).

64. 2016 Late Middle Palaeolithic occupations in Ciemna Cave, southern Poland, Journal of Field Archaeology, 41 (2), pp. 1-18 (co-authors: P. Valde-Nowak, B. Alex, B. Ginter, M. Krajcarz, T. Madeyska, B. Miękina, D. Stefański, P. Wojtal, M. Zając, K. Zarzecka-Szubińska).

65. 2016 The Middle Palaeolithic sequence of Ciemna Cave. Some aspects of the site formation process, Quartär, 63, pp. 33-46 (co-authors: P. Valde-Nowak, B. Alex, E. Boaretto, B. Ginter, D. Stefański, M. Zając).

\section{CHAPTERS}

66. 1987 The Late Glacial Environment and Palaeolithic Cultures in the Upper Vistula Basin (in:) J. M. Burdukiewicz, M. Kobusiewicz (eds.), Late Glacial in Central Europe: culture and environment, Wrocław, pp. 255-266 (co-authors: B. Ginter, J. K. Kozłowski).

67. 1992 Stefana Krukowskiego koncepcja pradnika, (in:) J. Lech, J. Partyka (eds.), Prof. Stefan Krukowski (1890-1982). Działalność Archeologiczna i jej znaczenie dla nauki polskiej, Prądnik. Prace i Materiały Muzeum im. prof. Władysława Szafera, 6, Ojców, pp. 5-10.

68. 1992 Excavations in the Duża Cave at Maczna Skała near Cracow (Southern Poland), (in:) Studies on cave sediments of the Cracow Upland (Poland), Folia Quaternaria, 63, Kraków, pp. 3-24 (co-authors: A. Dagnan-Ginter, B. Drobniewicz, J. Godawa, B. Miękina, E. Stworzewicz).

69. 1992 Excavations in the Zawalona Cave at Mników (Cracow Upland, Southern Poland), (in:) Studies on cave sediments of the Cracow Upland (Poland), Folia Quaternaria, 63, Kraków, pp. 43-76 (co-authors: S.W. Alexandrowicz, B. Drobniewicz, B. Ginter, J. K. Kozłowski, T. Madeyska, A. Nadachowski, M. Pawlikowski, Z. Szyndlar, M. Wolsan).

70. 1996 Kraków-Spadzista unit D: excavations 1986-1988, (in:) J. K. Kozłowski (ed.), The Upper Palaeolithic site Kraków-Spadzista: Units D, E and F (excavations 1986-1989), Folia Quaternaria, 67, Kraków, pp. 75-127.

71. 1997 Geochronologia osadnictwa paleolitycznego, (in:) K. Tunia (ed.), Z archeologii Małopolski: Historia i stan badań zachodniomałopolskiej wyżyny lessowej, Kraków, pp. 91-107.

72. 1997 Petrografical composition and provenance of siliceous artefacts on the archaeological sites in the regions of Spisz and the Pieniny Mountains (southern Poland), (in:) R. Schild, Z. Sulgustowska (eds.), Man and Flint. Proceedings of the VII ${ }^{\text {th }}$ International Flint Symposium, Warszawa-Ostrowiec Świętokrzyski, pp. 195-200 (co-authors: B. Drobniewicz, M. Doktor).

73. 1998 Lithic inventory, (in:) J. K. Kozłowski (ed.), Complex of Upper Palaeolithic Sites near Moravany. Western Slovakia: Vol. II Moravany-Lopata II (excavations 1993-1996), Kraków, pp. 43-83 (co-authors: B. Kazior, J. K. Kozłowski).

74. 2000 Long term stability of raw materials procurement systems in the Middle and Upper Paleolithic of Eastern Slovakia: A case study of the Topla/Ondava river valleys, (in:) Á. Ringer (ed.), Praehistoria: Volume 1, Miskolc, pp. 63-81 (co-authors: L. Kaminski, J. K. Kozłowski, B. Kazior, M. Pawlikowski). 
75. 2000 The Late gravettian in A. Pavlech's collections from Banka-Kopanice and BankaKnazovice, (in:) J. K. Kozłowski (ed.), Complex of Upper Palaeolithic Sites near Moravany. Western Slovakia: Vol. III Late Gravettian shouldered points horizon sites in the Moravany-Banka area, Nitra, pp. 73-119.

76. 2000 Excavations at Banka-Horné farské role site, (in:) J. K. Kozłowski (ed.), Complex of Upper Palaeolithic Sites near Moravany. Western Slovakia: Vol. III Late Gravettian shouldered points horizon sites in the Moravany-Banka area, Nitra, pp. 121-152 (co-authors: W. S. Alexandrowicz, L. Kaminská, B. Kazior, J. K. Kozłowski, M. Pawlikowski).

77. 2001 New Palaeolithic excavations in the Region of Cracow, (in:) Problemy paleografii późnego plejstocenu i holocenu, Grodno, pp. $77-79$ (co-authors: C. Escutenaire, V. Sitlivy, T. Kalicki, A. Zięba).

78. 2001 Badania wykopaliskowe w Jaskini Lokietka w Ojcowskim Parku Narodowym w latach 1998-2000, (in:) J. Lech, J. Partyka (eds.), Z archeologii Ukrainy i Jury Ojcowskiej, Ojców, pp. 323-336 (co-author: V. Sitlivy).

79. 2002 Les industries laminaires anciennes de Piekary et de Ksiecia Jozefa (Cracovie), (in:) M. Otte, J. K. Kozłowski (eds.), Préhistoire de la Grande Plaine du Nord de l'Europe. Les échanges entre l'Est et l'Ouest dans les sociétés préhistoriques: Actes du Colloque Chaire Francqui interuniversitaire au titre étranger Université de Liège, le 26 juin 2001, Études et Recherches Archéologiques de l'Université de Liège, 99, Liège: Université de Liège, pp. 39-45 (co-authors: C. Escutenaire, J. K. Kozlowski, V. Sitlivy, H. Valladas, N. Mercier, A. Zieba).

80. 2003 Taphonomy of the Gravettian site - Kraków Spadzista Street (B), (in:) J. W. F. Reumer, J. De Vos, D. Mol (eds.), Advances in Mammoth Research: Proceedings of the Second International Mammoth Conference Rotterdam, 16-20 May 1999, DEINSEA, 9, Rotterdam: Natural History Museum Rotterdam, pp. 557-562 (co-author: P. Wojtal).

81. 2004 Late Middle and Early Upper Palaeolithic Complexes of the Cracow region, Poland, (in:) Le Secrétariat du Congrès (eds.), Acts of the XIV ${ }^{\text {th }}$ Congress of the International Union for Prehistoric and Protohistoric Sciences, University of Liège, Belgium, 2-8 September 2001. Section 6: Le Paléolithique supérieur/The Upper Palaeolithic. General Sessions and posters, British Archaeological Reports International Series, 1240, pp. 305-317 (co-authors: V. Sitlivy, C. Escutenaire, T. Kalicki, A. Kolesnyk, J. Kozlowski, N. Mercier, N. Tisnerat-Laborde, H. Valladas, A. Zięba).

82. 2006 Późnośrodkowopaleolityczne stanowisko przy ul. Księcia Józefa w Krakowie, (in:) K. Szymczak, M. Przeździecki (eds.), In memoriam Valdemari Chmielewski. Księga poświęcona pamięci profesora Waldemara Chmielewskiego, Światowit. Supplement Series P, Prehistory and Middle Ages, 11, Warszawa, pp. 123-137.

83. 2006 The Middle-to-Upper Palaeolithic Transition in Cracow Region, (in:) Hugo Obermaier - Gesesllschaft für Erforschung des Eiszeitalters und der Steinzeit e. V. 48 Tagung der Gesellschaft in Köln, 18-22 April 2006 preact, pp. 29-30 (co-authors: V. Sitlivy, A. Zięba).

84. 2006 Le site paleolithique de Kharukhyn, Mongolie centrale (Bulgan Aimac), (in:) L. Domańska, Young-jo Yi (eds.), Suyanggae and her neighbours: $11^{\text {th }}$ International Symposium: New Ideas and Discoveries of the Paleolithic and Mesolithic Research All Over the Old World, Łódź, pp. 139-167 (co-authors: V. Sitlivy, A. Zięba, T. Kalicki, C. D. Tseveendorj, B. Gunchinsuren, Y. Tserendagva).

85. 2007 The formation of mammoth bone accumulation at the Gravettian site KrakówSpadzista B+B1, (in:) J. K. Kozłowski (ed.), Man/Mammoth interactions: bone, beds and late Gravetian occupations at Kraków-Spadzista, Folia Quaternaria, 77, Kraków, pp. 5-30 (co-authors: T. Kalicki, J. K. Kozłowski, A. Krzemińska, P. Wojtal). 
86. 2008 History of investigations, (in:) V. Sitlivy, A. Zięba, K. Sobczyk (eds.), Middle and Early Upper Palaeolithic of the Krakow Region: Piekary IIa, Monographies de Préhistoire Générale, 6, Bruxelles, pp. 5-16 (co-authors: V. Sitlivy, A. Zięba, W. Morawski).

87. 2008 The lithic assemblages, (in:) V. Sitlivy, A. Zięba, K. Sobczyk (eds.), Middle and Early Upper Palaeolithic of the Krakow Region: Piekary IIa, Monographies de Préhistoire Générale, 6, Bruxelles, pp. 57-148 (co-authors: A. Zięba, V. Sitlivy).

88. 2008 Conclusion, (in:) V. Sitlivy, A. Zięba, K. Sobczyk (eds.), Middle and Early Upper Palaeolithic of the Krakow Region: Piekary IIa, Monographies de Préhistoire Générale, 6, Bruxelles, pp. 197-199 (co-authors: V. Sitlivy, A. Zięba).

89. 2009 History of investigations, (in:) V. Sitlivy, A. Zięba, K. Sobczyk (eds.), Middle and Early Upper Palaeolithic of the Krakow Region: Księcia Józefa, Monographies de Préhistoire Générale, 7, Bruxelles, pp. 3-10 (co-authors: V. Sitlivy, A. Zięba, H. Valladas, N. Mercier, N. Tisnerat).

90. 2009 Lithic assemblages, (in:) V. Sitlivy, A. Zięba, K. Sobczyk (eds.), Middle and Early Upper Palaeolithic of the Krakow Region: Księcia Józefa, Monographies de Préhistoire Générale, 7, Bruxelles, pp. 17-167 (co-authors: V. Sitlivy, A. Zięba, A. Kolesnik).

91. 2009 Conclusion, (in:) V. Sitlivy, A. Zięba, K. Sobczyk (eds.), Middle and Early Upper Palaeolithic of the Krakow Region: Księcia Józefa, Monographies de Préhistoire Générale, 7, Bruxelles, pp. 193-194 (co-authors: V. Sitlivy, A. Zięba).

92. 2010 Palaeolithic in the Cracow Region, (in:) N. J. Conard, A. Delagnes (eds.), Settlement Dynamics of the Middle Paleolithic and Middle Stone Age, Volume III, Tübingen, pp. 235-248 (co-authors: A. Zięba, V. Sitlivy).

93. 2014 Refiting of flint artefacts, (in:) V. Sitlivy, A. Zięba, K. Sobczyk, A. Kolesnik, The middle-to-upper palaeolithic Księcia Józefa open-air site (Krakow, Poland): lithic technology and spatial distribution, Universitätsforschungen zur prähistorischen Archäologie, 250, Bonn, pp. 15-478 (co-authors: V. Sitlivy, A. Zięba, A. Kolesnik).

94. 2014 Loess cover and Palaeolithic sites in Cracow, (in:) Z. Jary, P. Mroczek (eds.), Kukla Loessfest' $14-7^{\text {th }}$. Loess Seminar: International Conference on Loess Research. In memory of George Kukla. Abstract and field guide book, Wrocław, pp. 54-55 (co-authors: M. Łanczot, P. Mroczek, J. Wilczyński, T. Madeyska, M. Komar, A. Bogucki, B. Hołub).

95. 2015 New radiocarbon dating of animal bones from Ciemna Cave - a Micoquian site in Poland, (in:) A. Maier (ed.), Hugo Obermaier Gesellschaft für Erforschung des Eiszeitalters und der Steinzeit e.V., 57 ${ }^{\text {th }}$ Annual Meeting in Heidenheim, Erlangen, pp. $43-44$ (coauthors: M. Krajcarz, M. T. Krajcarz, T. Madeyska, P. Wojtal, B. Ginter, P. Valde-Nowak, D. Stefański, M. Zając, K. Zarzecka-Szubińska, B. Alex).

96. 2015 A New look at an old site: Studies of the Kraków Spadzista site 1968-2013, (in:) S. Sázelová, M. Novák, A. Mizerová (eds.), Forgotten times and spaces: New perspectives in paleoanthropological, paleoetnological and archeological studies, Brno, pp. 169-190 (co-authors: P. Wojtal, J. Wilczyński).

97. 2015 Kraków Spadzista site - History of the research, (in:) P. Wojtal, J. Wilczyński, G. Haynes (eds.), A Gravettian Site in Southern Poland: Kraków Spadzista, Kraków, pp. 5-18.

98. 2015 Natural environment of the Gravettian settlement in the Kraków Spadzista site based on palaeogeographical interpretation of loess-palaeosol sequences, (in:) P. Wojtal, J. Wilczyński, G. Haynes (eds.), A Gravettian Site in Southern Poland: Kraków Spadzista, Kraków, pp. 19-49 (co-authors: M. Łanczot, P. Mroczek, T. Madeyska, M. Komar, B. Hołub, B. Żogała, J. Wilczyński). 
99. 2017 Contributions to the Middle Palaeolithic in the Argolid, (in:) J. K. Kozłowski (ed.), Contributions to the prehistory of Greece and the Aegean: 25 years of the Polish-Greek cooperation in prehistoric research, Kraków, pp. 29-46.

100. 2018 Kraków Spadzista - A Gravettian site of mammoth hunters, (in:) P. Valde-Nowak, K. Sobczyk, M. Nowak, J. Źrałka (eds.), Multas Per Gentes Et Multa Per Saecula. Amici Magistro Et Collegae Suo Ioanni Christopho Kozłowski Dedicant, Kraków, pp. 115-122 (co-authors: P. Wojtal, J. Wilczyński).

\section{POPULAR SCIENCE ARTICLES}

101. 2008 Neandertalczyk i Homo sapiens w jaskini Klissoura na Peleponezie, Alma Mater, miesięcznik Uniwersytetu Jagiellońskiego, 99/2008, pp. 127-131.

Prepared by Jakub Skłucki 